\title{
Stochastic analysis of the main macro-economic indicators characterizing higher education in Romania during 2001- 2016
}

\author{
Ani MATEI \\ National School of Political Science and Public Administration, Bucharest, Romania
}

Silvia Elena CRISTACHE

The Bucharest University of Economic Studies, Bucharest, Romania

Erika MARIN

The Bucharest University of Economic Studies, Bucharest, Romania

Florica Georgeta ROTARU

National School of Political Science and Public Administration, Bucharest, Romania flory_georgeta_rotaru@yahoo.com

\begin{abstract}
The education system in Romania will have to take into account the need to give people the skills and abilities needed to adapt quickly to changing labor markets. In the current context the study is based on comparative statistical analyses and correlations in the field of human resources in the higher educational system, analyses based on secondary data or information provided by the Romanian Statistical Yearbook published by the National Statistics Institute and other publications by public institutions in Romania such as: The National Bank, The Ministry of National Education, etc. The paper presents the major trends and shift in macroeconomic indicators specific to higher education and proposes a model to better understand the relationship between these indicators.In conclusion without continuous training and mobile resource salary comparable to those of EU countries, along with an infusion of capital proper, cannot achieve highly educated people well integrated, civilized, cultivated so as to reach sustainable growth on the long term. In this regard the Ministry of National Education and RQAAHE launched nationwide research projects involving both teaching staff in higher education, and the alumni and students. In order to decrease unemployment among young people (24-30 years) were involved in these projects and employers so that there is a better relationship between skills acquired in the continuous education and labor market; projects that are underway or to be implemented.
\end{abstract}

Keywords: high education system, study programs, macroeconomic indicators, labor market, correlation and regression method, degree of inclusion in education.

\section{Introduction}

From the beginning of 1990's, the European University Association promoted the importance of the higher education quality within the European Environment of the higher education. Nevertheless, only at the Ministerial Conference from Berlin 2003 was triggered the impulse for a new development in a better understanding of the purpose of universities in assuring the quality in the higher education as presented in the Communiqué of the Ministerial Bologna Follow-up Conference, Berlin, 2003.

Further, in 2009, on the occasion of the Leuven / Louvain-la-Neuve Communiqué the importance of lifelong learning, the widening access to higher education as well as a higher degree of mobility within the EU were particularly stressed. By 2020, at least $20 \%$ of those graduating in the European Area of Higher Education will have had to study or participate in a training program abroad. (Communiqué of the Conference of European Ministers Responsible for Higher Education, 2009) 
The European Area of Higher Education was globally approached as a consistent and competitive space, a market with strong competitive flows and as a way of integrating the national systems into a global European system. Within this global system, the universities would have autonomy, would be diversified and, especially, compatible in terms of structures and programs, in order to facilitate mobility of staff and students and, as a consequence increase their employability on the European labor PICBE | 1159 market (Zaharia and Marinaș, 2005).

The purpose of Tertiary Education in the knowledge society is recognized both at the level of the European Union and the Member States. The Tertiary Education is expected to have an important contribution in achieving the Lisbon Treaty's objectives regarding the growth, prosperity and social cohesion.

Bologna Process and the Lisbon process configure the European education and quality assurance in education. The Lisbon European Council established that by 2010, Europe should have become "the most competitive and dynamic economy based on knowledge and able to sustain in a short period of time economic growth, more jobs and better."

The quality level of the higher education must pass the comparison test, on an international scale, to improve the management and responsibility, to increase financing and diversify the financing sources (Bergen, 2005).

The main European directions regarding the financing of the higher education institutions are tied to the purpose that the system has in implementing Europe 2020 Strategy. The main action directions refers to: the necessity of growing public financing for the higher education, growing autonomy in managing the own financial resources, focus on results by establishing a direct connection among the results of the education process and the public funds assigned to these, encourage the diversification of financing resources as well as creating strategic partnerships with research institutions, enterprises and regional authorities (Popescu and Bratianu, 2004).

Access to high quality education and training is fundamental to the affirmation of Europe as a knowledge society and as a major actor on a globalized world economy. The European countries agree on common goals but education policy is determined by each Member State individually.

Starting with 2005-2006 academic year, Romania reorganised the higher education on the three successive study cycles recommended by the Bologna Process. Moreover, Romanian education experienced liberalization of the first cycle of study and the transformation of this into a mass higher education as well as the opening to the internationalization of the study programs for young people (Korka, 2009).

Romania has adopted in 2011 a new legislation regarding the education system followed by several changes and completions, enhanced new strategies in the alignment with the updated European standards regarding the education system. (National Institute of Statistics, 2012).

The Romanian educational policies are consistent with the European Commission and Member State's initiatives regarding the development of educational systems in order to meet the priority objective of the European Union with respect to developing a knowledge-based economy. In Romania, the implementation of Erasmus student mobility is reflected on the number of students who benefited from mobility, that number has grown steadily from year to year. Nevertheless, compared to the average EU level, the students' participation in this programme remains quite low. (European Union- DG Education and Culture, 2011) 
Romania committed to promote policies compatible with the European ones concerning equal opportunity, mobility in higher education, education in foreign languages as well as racial and ethnic non-discrimination. Secondary and higher education have experienced the most pronounced reductions in the number of pupils / students enrolled in school / university year 2014-2015 compared to the previous one (in 2015 there were 49.000 pupils as well as 37.000 students / trainees registered) (National Statistics Institute, 2015).

\section{Research data and methodology}

This study is based on analyses and comparative statistical correlations in education; research analysis is based on secondary data provided by the Romanian Statistical Yearbook (2007 -2015) and "The Romanian Education system" published by the National Institute of Statistics and other publications from Romanian public institutions (e.g. National Bank of Romania).

First, the analysis describes the main trends in the macroeconomic variables that characterize the education system, such as: school population represented by number of students studying in bachelor programmes, teaching personnel and degree of educational school enrolment of the population.

Next, an econometric model is developed, tested and validated based on the trends shaping the high-university educational system Romania in the period 20012016 using EViews.

The choice of these methods is motivated by the following objectives: the accurate quantification of the effects produced by all the factors, selecting the main factors, measuring the intensity and direction of links existing between indicators characterizing higher educational system.

\section{Statistical methods to characterize the evolution and structure of the macroeconomic indicators that characterize the high-university educational system in Romanian during 2001-2016 \\ Analysis of dependencies between macro-economic indicators that influence and characterize the high-university educational system}

The results of the national education system are measured using indicators expressing the potential of the system to create qualified labor force, adapted to the economic and social development needs. The number of the institutions of higher education increased continually until 2002/2003 when there were 70 private institutions of higher education. After this period, the number of private institutions of higher education has a decreasing trend. In the 2013/2014 academic year, the indicator reached the value of 47 private institutions.

In the 2013/2014 academic year there are 775 faculties within the institutions of higher education, of which 590 are within public universities. Studying the evolution of the higher education institutions assume an examination of the structure mutations, as well as a analysis of the dynamics of these mutations. It can be appreciated an increasing share of public universities in total of $64 \%$ in $2013 / 2014$ up to $69 \%$ in $2014 / 2015$. (See figure 1, 2).

As a consequence of the demographic evolution in the latest years and due to the phenomena of migrations, the population decreased considerably. The slow, but continuous, process of population aging lead to a decrease in the schooling population. In $2012-2013,12.4 \%$ from the total schooling population were students. (Data source: National Institute of Statistics- Social Trends, 2012). 


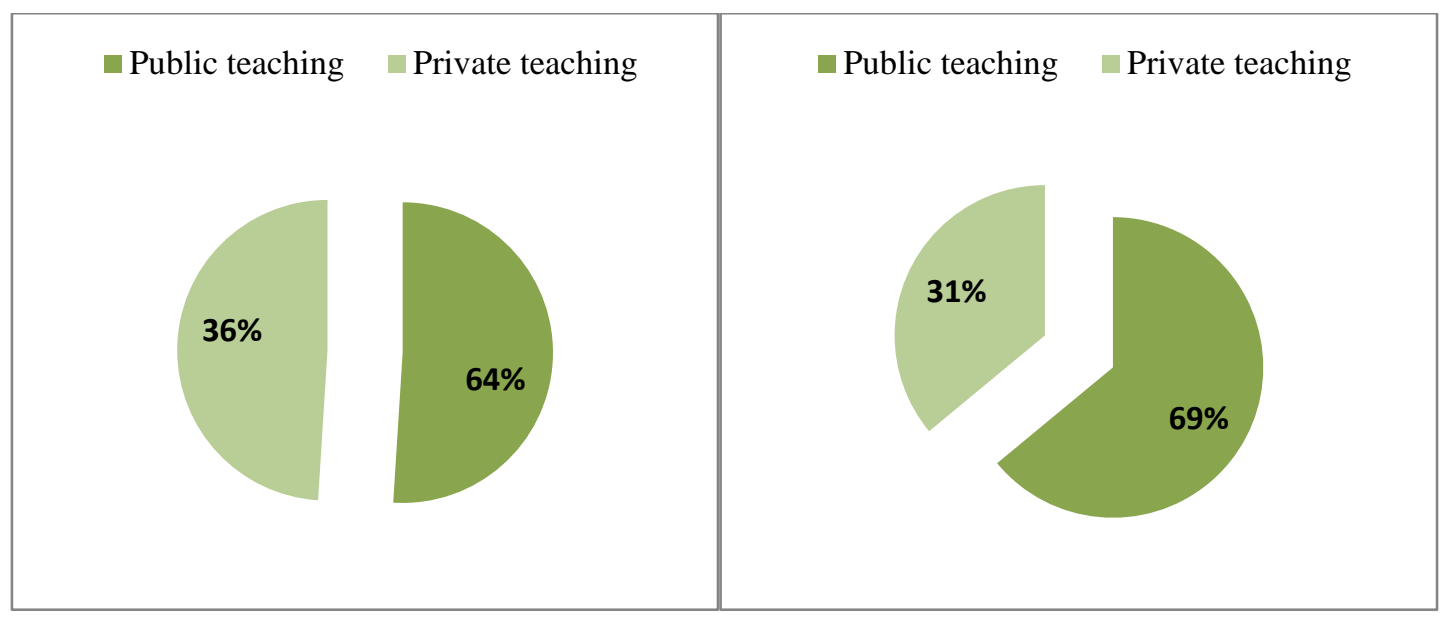

PICBE | 1161

Figure 1. Share of institutions in

Higher education 2013/2014
Figure 2. Share of institutions in

Higher education 2014/2015

Source: Processing by-Romanian Statistical Yearbook 2015.

At the same time, comparing to $2000 / 2001$, the number of students that follow a professor career in 2012/2013 decreased from 21 to 15 students. The structure on genders of the population does not show significant changes, the female population being almost equal to the male one. (The National Institute of Statistics - Social Trends, 2012/2013). The number of students registered for faculty increased successively in 2001-2007 from 582.000 people in 2001 to 907.000 people in 2007. After 2007 this indicator had a decreasing evolution, registering a minimum value in 2016 of 409.000 students. The average rate of decreasing students registered for faculty during 20012016 was of $2.48 \%$ representing an average number of 12 students/ year (See figure 3).

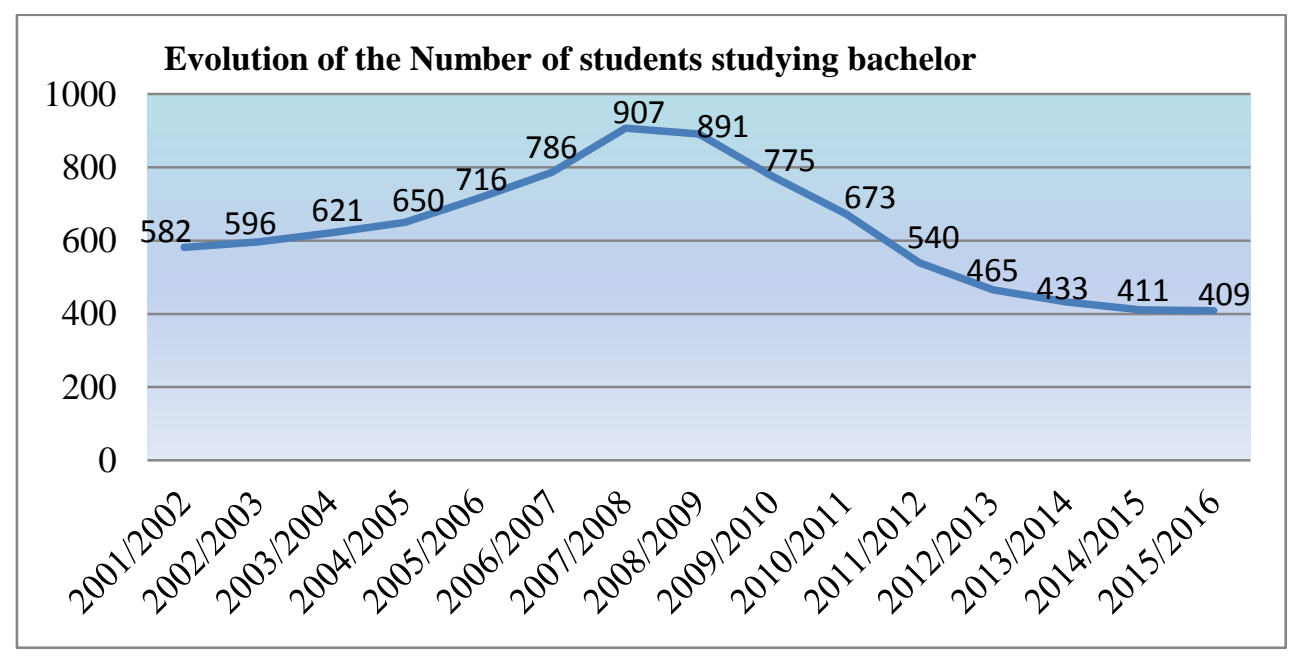

Figure 3. Evolution of the number of students studying bachelor

Source: Processing by-Romanian Statistical Yearbook 2015 (Note: the value of 2016 is estimated)

The gross enrolment ratio had an upward trend during 2001-2010 with maximum of $86.5 \%$ in 2010 . This macroeconomic indicator recorded an average growth rate during 2001-2016 of $0.98 \% / y e a r$ and an average increase of $0.74 \mathrm{pp}$. / year.

In contrast with the enrolment degree, the evolution of teaching personnel in higher education has oscillated in the period 2001-2016, decreasing, on average, with 133 persons / year (an average annual decrease rate of 0.47\%) (See Figures 4 and 5).

The explanation lies in the low level of expenses for education as a percentage of GDP that was assigned in Romania compared to other European Union member states, but also because of the insufficient financial resources from the private sector. During 2001-2014 a significant increase in the number of students registered for Distance education was recorded. The study programs are organized in 6 groups of 
specializations, for all the fields of study: technical, pharmaceutical, economic science, juridical science, teaching and arts.
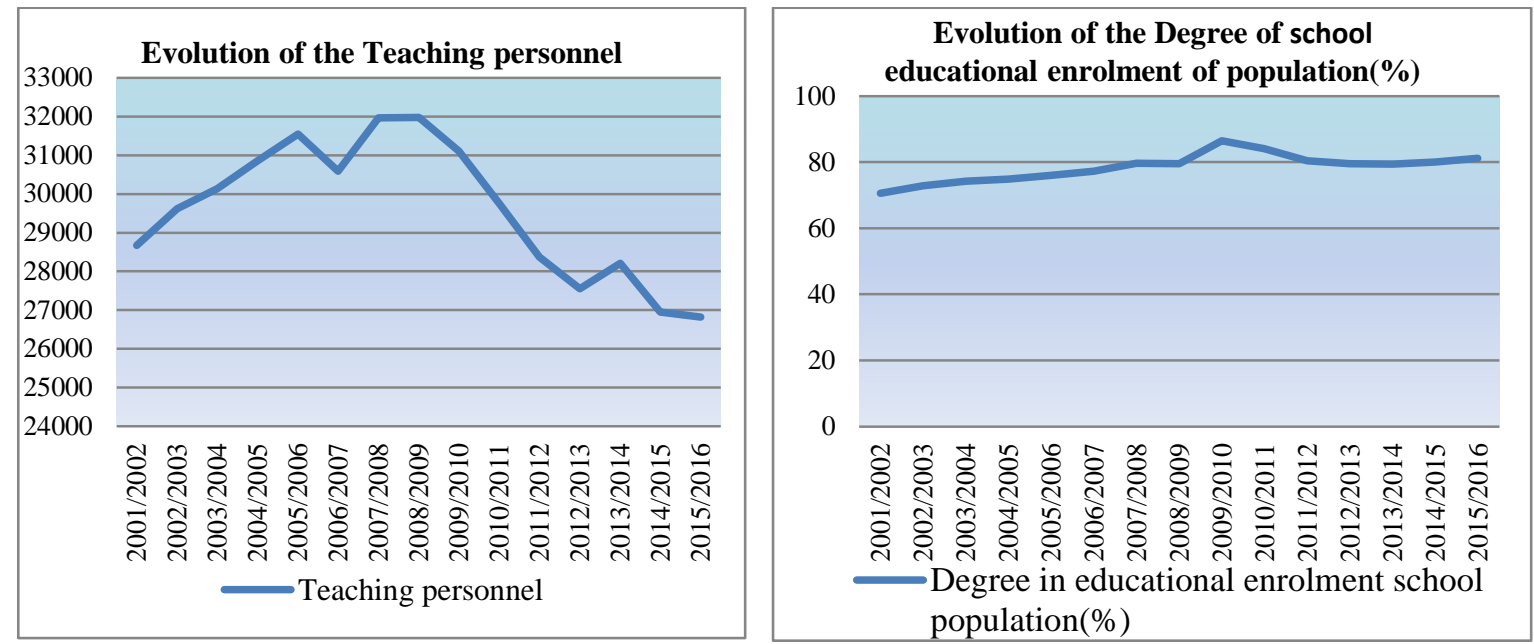

PICBE | 1162

Figure 4. Evolution of the teaching personnel and degree of school educational enrolment of population in 2001-2016

Source: Processing by-Romanian Statistical Yearbook 2015 (The value of 2016 is estimated).

The structure of the graduates, on groups of specialization at the end of $2011 / 2012$ is as follows: from the total, significant shares were registered inside the faculties with specializations in the universities (30.4\%). economic (25.2\%), technical (21.7\%) (The National Institute of Statistics- Social Trends, 2012).

At the current moment similar trends are registered regarding the share of graduates from universities. If before 1990 the abandonment rate was very low, the quick economic and social transformations in the last decade together with the economic crisis lead to a significant and sudden increase in the abandonment rate among the young population for all level of education (See figure 6).

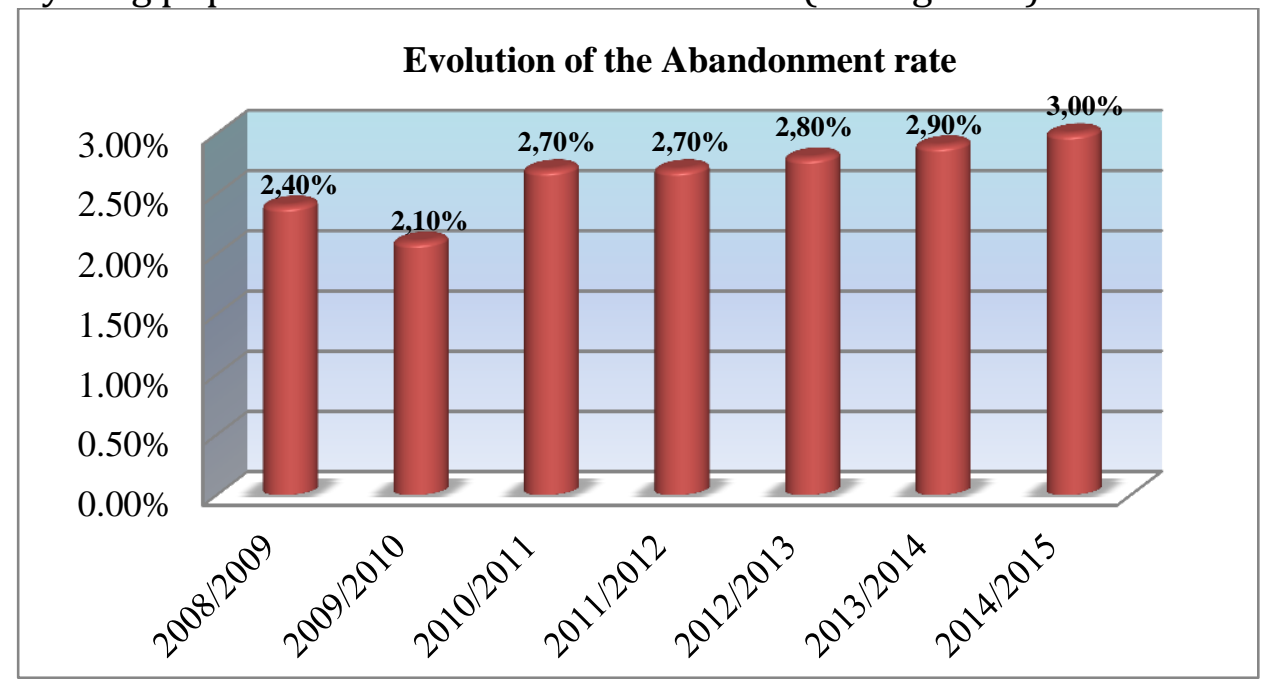

Figure 5. Evolution of the abandon rate (\%) during 2008-2015

Source: Processing by-Romanian Statistical Yearbook 2015 (The values of 2014 and 2015 are estimated).

At present, the abandonment affects, mainly, the population from the rural area. Causes of these school leavers are complex and multiple, like: poor economic situation, external migration, disorganized family environment, etc.

Analysis of dependencies between variables that influencing the high-university educational system in Romanian during 2001-2016 
For the completion of the study regarding the characterization of the higher education system in Romania, the second stage of the statistical analysis is presented, by measuring the impact on the number of teachers.

Hence, the following econometric model is proposed for investigation: the relationship between the number of teachers in higher education (dependent variable) and two independent variable: the investment in education ( $\mathrm{x}_{1}$ - expressed in million PICBE 1163 euros) and the average gross monthly salary ( $x_{2}$-expressed in national currency RON/month). All indicators are collected for the analysis period of 2001 - 2016

By applying a multiple linear regression model using EViews software package the following results summarized in Table 1 were obtained:

Table 1. Output EVIEWS for the multiple regression model

\begin{tabular}{|c|c|c|c|c|}
\hline \multicolumn{5}{|c|}{$\begin{array}{l}\text { Dependent Variable: TEACHING_PERS } \\
\text { Method: Least Squares } \\
\text { Date: } 02 / 25 / 17 \text { Time: } 22: 18 \\
\text { Sample: } 20012015 \\
\text { Included observations: } 15 \\
\text { TEACHING_PERS=C(1)+C(2)* REAL_INVESTMENT+C(3)* } \\
\quad \text { AVERAGE_GROSE }\end{array}$} \\
\hline & Coefficient & Std. Error & t-Statistic & Prob. \\
\hline $\mathrm{C}(1)$ & 30212.33 & 742.7916 & 40.67403 & 0.0000 \\
\hline $\mathrm{C}(2)$ & 11.26730 & 2.439786 & 4.618149 & 0.0006 \\
\hline $\mathrm{C}(3)$ & -1.760669 & 0.485879 & -3.623677 & 0.0035 \\
\hline R-squared & 0.768077 & \multirow{4}{*}{\multicolumn{2}{|c|}{$\begin{array}{l}\text { Mean dependent var } \\
\text { S.D. dependent var } \\
\text { Durbin-Watson stat }\end{array}$}} & 29606.40 \\
\hline Adjusted R-squared & 0.712756 & & & 1760.207 \\
\hline F-statistic & 12.07647 & & & 1.705865 \\
\hline Prob(F-statistic) & 0.001337 & & & \\
\hline
\end{tabular}

The following results of multiple regression function using linear regression model of multi-factorial were obtained:

$$
\mathrm{Y}_{\mathrm{x}_{1}, \mathrm{x}_{2}}=30212.33+11.26 \mathrm{x}_{1}-1.76 \mathrm{x}_{2}
$$

The intercept has no economic significance.

The regression coefficient b1 is 11.26 showing a positive relationship between investments in education and teaching staff. For each additional million euros invested in education one can expect an average increase of 11.3 persons in teaching staff, while holding the average gross monthly salary in higher education constant.

Since $t=4.61$ and $p$-value $=0.0006<0.05$ the coefficient $b_{1}$ is valid at a 0.05 significance level..

The second regression coefficient b2 is negative $(-1.76)$, presenting a negative correlation between teaching staff (persons) and the average gross monthly salary. The explanations might be specific to the last decade developments in both the Romanian economy and the Higher Education system. On one hand, there was some real term decreases in salaries (with a major decrease of 25\% in salaries in 2010 as part of de governmental decision trying to limit the effects of financial crisis). This reduction did not diminished the number of personnel in education. On the other hand, in the last years the salaries in higher education grew but the number of teaching staff decreased as a result of the important reduction in number of students especially in private universities (the decrease in the number of students is due to demographic changes but as well the very small rate of passing the Baccalaureate exam. 
Since $t=-3.62$ and $p$-value $=0.0035<0.05$ the coefficient $b_{2}$ is valid for at a 0.05 significance level.

The intensity of the relation between the variables of this multi factorial regression model are measured by the multiple correlation ratio $\left(R_{y / x 1, x 2}\right)$ whose value is 0.87 , the relationship between the variables is strong and direct. The coefficient of determination shows a 76.8\% from the variation of the teaching personnel registered PICBE | 1164 for faculty is explained by the influence of the real investment in education, average gross nominal monthly salary in education. The $32.2 \%$ difference represents the influence of other factors (abandon rate, real GDP in education, etc.). Checking the accuracy of the multiple regression models and of the multiple correlation ratios, based on "Fisher" criterion, leads to the following conclusion: because the probability Significance $F$ is less than 0.05 the multiple regression models is valid, with a significance threshold of 0.05 .

The Durbin Watson test is used for detect autocorrelation of order 1 between residuals. The Durbin-Watson test, used in the regression analysis, registered a value of: $D W_{\text {calc }}=1.70$, value compared with the critical values of statistics for $\alpha=0.05, p=3$ and $\mathrm{n}=15 ; \mathrm{d} 1=0.95 \mathrm{si}_{2}=1.54$ which indicates that errors are independent

Likewise, from the correlogram it can be said that the point from the graphic network (figure 6) are uniformly spread concluding that the relation between the included variables in the multi factorial model is linear, direct and significant.

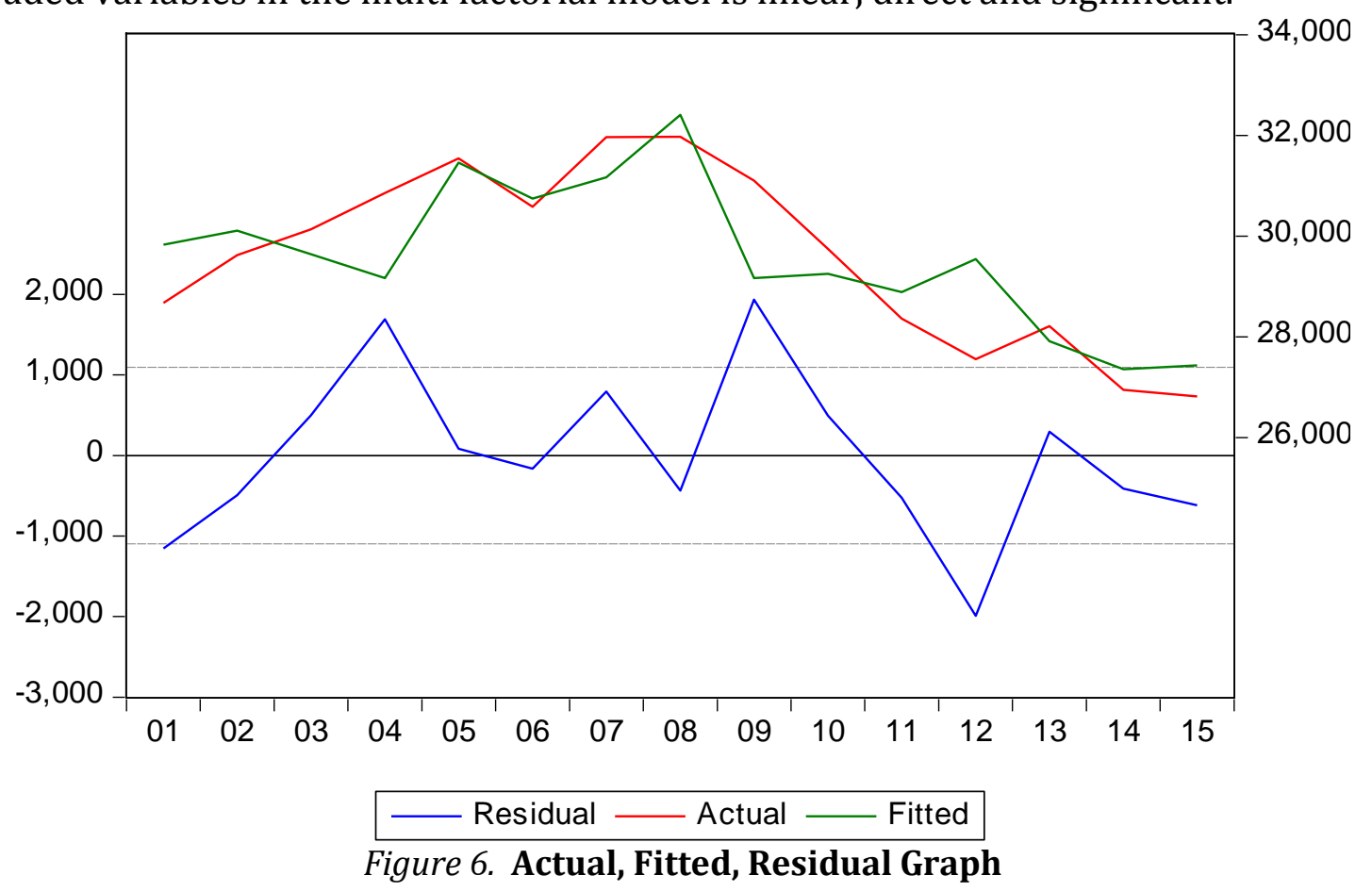


To prove the normality of errors using Jarque-Bera test one observes that $\mathrm{JB}_{\text {calc }}=0.09$ $<\chi^{2}$ tabel$=7.81$ which means that the errors are normally distributed (See figure 7).

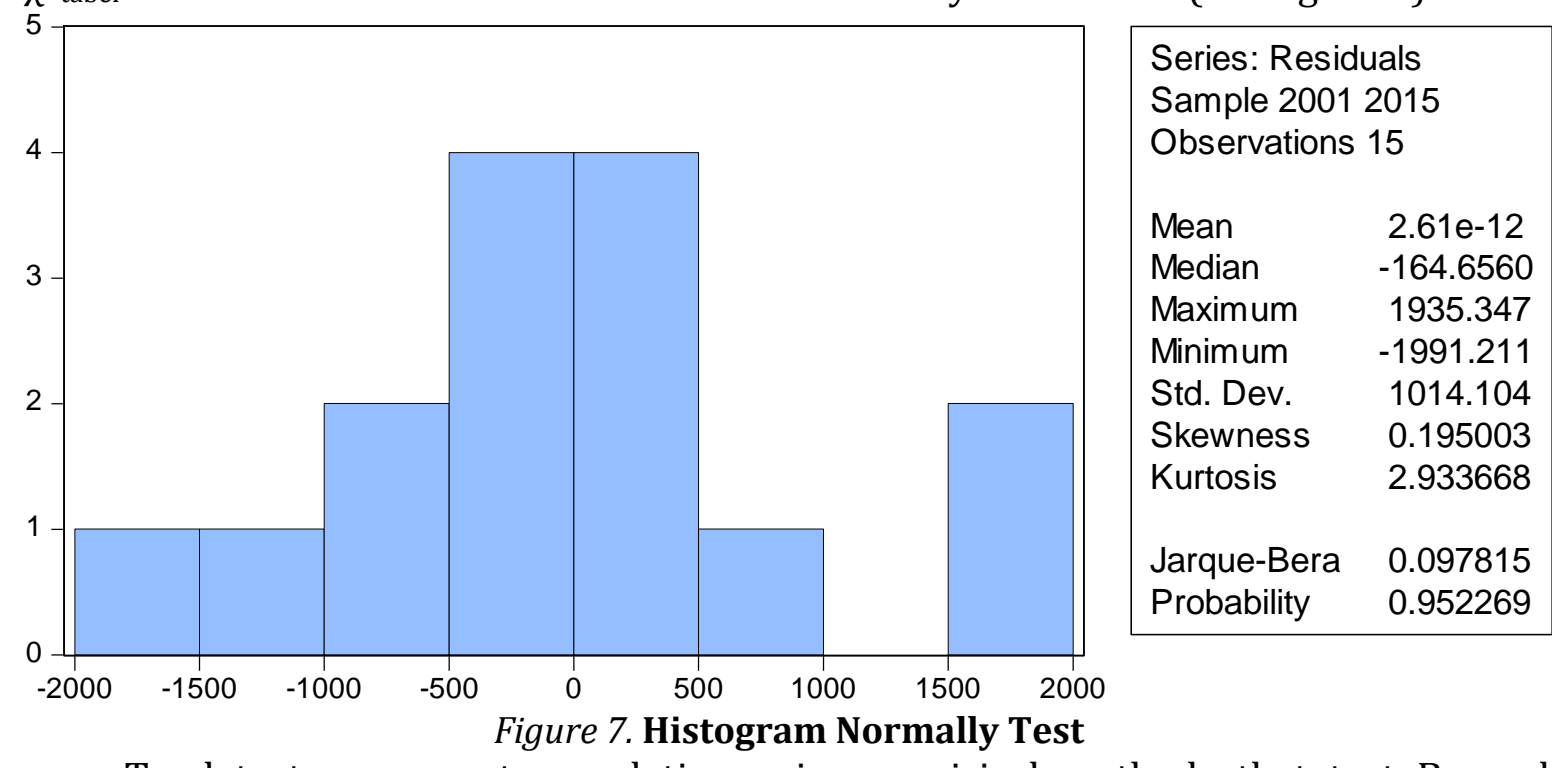

PICBE | 1165

To detect errors autocorrelation using empirical methods that test BreuschGodfrey. With this test will analyse the existence of autocorrelation of order $\mathrm{k}, \mathrm{k} \neq 1$. It is assumed that the error of the regression model is given by the equation:

$$
\varepsilon_{t}=\rho_{1} \varepsilon_{t-1}+\rho_{2} \varepsilon_{t-2}+\ldots+\rho_{k} \varepsilon_{t-k}+v_{t}, \text { for } \mathrm{t}=\mathrm{k}, \ldots, \mathrm{n}, \text { but } v_{t} \sim \mathrm{N}\left(0, \sigma_{v}^{2}\right)
$$

By applying statistical software (EViews) the statistical probability $\mathrm{F}$ is 0.94

(high) and $\mathrm{F}_{\text {statistic }}<\mathrm{F}_{\text {tabel }}(0.06<3.80)$ errors are homoscedastic ( see Table 2 ).

Table 2. The results of Breusch-Pagan-Godfrey Test for Heteroskedasticity

\begin{tabular}{|llll|}
\hline Heteroskedasticity Test: Breusch-Pagan-Godfrey & \\
\hline \hline F-statistic & 0.060538 & Prob. F(2,12) & 0.9415 \\
Obs*R-squared & 0.149832 & Prob. Chi-Square(2) & 0.9278 \\
\hline
\end{tabular}

In conclusion, the model provides us a starting point in understanding the factors influencing the development of the analysed phenomena, establishing the practical measures for assuring the optimal development for the number of teachers.

\section{Conclusions}

The Romanian Higher Education system, as integrating part of the European Education system has undergone significant changes in the past decades. Those changes can be reflected when studying the changes in the levels, structure and dynamics of the higher education macroeconomic indicators, as presented in the paper. Besides the quantitative changes, the qualitative changes have to be implemented in order to achieve all the country's targets.

The problem of the quality in the Romanian education system is still a sensitive subject that requires a great attention. Unfortunately the making of the quality commissions, both for the higher education and the high school did not deliver the expected solution for the real compatibility of the Romanian and European education system and why not, the global one.

Teaching staff essential element in developing the educational process is an indicator with deep implications in determining the efficiency and quality of university education system. Studying the evolution of teachers, it involves an examination of structural changes and their dynamics analysis 
Therefore the result of the national education system is measured by indicators expressing its ability to create the required skilled labor force, adapted to the requirements of economic and social development. Only the staffs' continuous lifelong learning, allowance for resources comparable to other European countries as well as sound investments in the higher education system could give the basis of quality higher education with well integrated students on the labor market.

PICBE | 1166

\section{References}

Andrei, T., Bourbonnais, R. (2008). Econometrie, Economica Publishing house, Bucharest. Bergen. (2005), "Detailed work program on the implementation of the objectives of education and training in the EU", the Council of Ministers of Education responsible for Higher Education (Communiqué of the Conference of European Ministers Responsible for Higher Education, Bergen), 19-20 May 2005.

Communiqué of the Conference of European Ministers Responsible for Higher Education. (2009). The Bologna Process 2020 - The European Higher Education Area in the new decade, Leuven and Louvain-la-Neuve, 28-29 April.

Cristache, S.E., Vuta, M.,Gruiescu, M. (2011). "Model to characterize the Romanian educational system between 2001 - 2010" presented within the International Conference GEBA, Iasi, 540-554.

European Union, DG Education and Culture. (2011). Erasmus - Facts, Figures \& Trends; The European Union support for student and staff exchanges and university cooperation in 2009/2010, Bruxelles.

INSE Romania (2012/2013), Social Trends, Bucharest, http://www.insse.ro.

INSE Romania. (2005). Report on the state of the national education system, Bucharest, http://www.insse.ro.

INSE Romania. (2005-2015). Statistical Yearbook of Romania, National Institute of Statistics, http://www.insse.ro.

INSE Romania. (2011-2012). Summaries economic and social status, Bucharest, http://www.insse.ro.

INSE. (2015). National Statistics Institute Press-No. 294/20 November 2015.

Korka, M. (2009). Quality education for the labor market, Universitara Publishing house, Bucharest, 35-45.

Legea Educației Naționale. (2011). State of Education 2010, Draft Law on National Education and lifelong learning lifetime, MECT, Bucharest

Popescu, S. and Brătianu, C. (2004). Guide quality in higher education, Calypso Projects, the Bucharest University Press, Bucharest

Romanian Agency for Quality Assurance in Higher Education. (2006). "External evaluation methodology, standards, reference standards and list of performance indicators of the Romanian Agency for Quality Assurance in Higher Education", Bucharest, 80-90.

Zaharia, S.E., Marinaș L. (2005). Partners for Excellence in Europe knowledge. Romanian University in the context of the "Bologna" and "Lisbon", vol. 1,National Agency for Partnership between Universities and Economic Environment - Society, Bucharest. 